\title{
REVIEW
}

\section{Genomics approaches to unlock the high yield potential of cassava, a tropical model plant}

\author{
Shengkui ZHANG ${ }^{1,2}$, Ping'an MA ${ }^{1}$, Haiyan WANG ${ }^{1}$, Cheng LU $^{1}$, Xin CHEN $^{1}$, Zhiqiang XIA ${ }^{1}$, Meiling ZOU ${ }^{1}$, \\ Xinchen $\mathrm{ZHOU}^{1}$, Wenquan WANG $(\bowtie)^{1,2}$ \\ 1 Institute of Tropical Biosciences \& Biotechnology, Chinese Academy of Tropical Agricultural Sciences, Haikou 571101, China \\ 2 Key Laboratory of Biology and Genetic Resources of Tropical Crops of Ministry of Agriculture, Haikou 571101, China
}

\begin{abstract}
Cassava, a tropical food, feed and biofuel crop, has great capacity for biomass accumulation and an extraordinary efficiency in water use and mineral nutrition, which makes it highly suitable as a model plant for tropical crops. However, the understanding of the metabolism and genomics of this important crop is limited. The recent breakthroughs in the genomics of cassava, including whole-genome sequencing and transcriptome analysis, as well as advances in the biology of photosynthesis, starch biosynthesis, adaptation to drought and high temperature, and resistance to virus and bacterial diseases, are reviewed here. Many of the new developments have come from comparative analyses between a wild ancestor and existing cultivars. Finally, the current challenges and future potential of cassava as a model plant are discussed.
\end{abstract}

Keywords cassava, genomics, yield potential, adaptability, tropical model

\section{Introduction}

Model plants such as Arabidopsis and rice are extensively used for the discovery of genes and for the validation of their function and interactions [1]. Progress in genomics technology, especially rapid genome-sequencing methods, has enabled development of universal model biology for organisms that survive in diverse ecological environments. For example, setaria has been used as a model for Panicoideae crops and C4 photosynthesis [2-4]. Plant species from the tropics, such as cassava, rubber tree, sugarcane, banana, coconut and medicinal plants, are extremely diverse and supply considerable economic or ecological value. Such tropical species share some biological properties in their adaption to high temperature

Received November 25, 2014; accepted December 29, 2014

Correspondence: wangwenquan@itbb.org.cn and light, plentiful rainfall, survival during drought and in barren soil, and efficient biomass accumulation. However, knowledge of the physiology and molecular biology of tropical plants is limited.

\section{The essential tropical environments and their genetic diversity}

The tropics is a geographic zone from $23.5^{\circ} \mathrm{S}$ latitude (regression line) to $23.5^{\circ} \mathrm{N}$ latitude centered to the earth's equator and is enriched with agroclimatic resources, including solar radiation $\left(3712-5917 \mathrm{MJ} \cdot \mathrm{m}^{-2} \cdot \mathrm{d}^{-1}\right)$, temperature (the average annual temperature $\mathrm{T} \geqslant 20^{\circ} \mathrm{C}$ ) and rainfall (the mean annual rainfall ranges from 1600 to $2500 \mathrm{~mm}$ ), which varies seasonally. Therefore, the tropics have great species biodiversity compared to temperate and polar zones in terrestrial and oceanic environments. Mainly due to the rainfall difference, the tropics have been divided into humid rainforest and dry savanna ecological subtypes.

More than two-thirds of the higher plant species that are distributed in the tropics have been described, including many candidate economic plants with a huge potential for utilization in food, feed, bioenergy and biomaterials in industrial processes, for example, sugarcane, banana, cassava, rubber tree, palms, coffee, ornament plants and medicinal plants. Furthermore, the tropical rainforests are important for the stability of environments for human living, significant impacts on global carbon cycling and climate, and, along with savanna, are important in habitat and landscaping for human beings. There are more than 50 million $\mathrm{km}^{2}$ of tropical terrestrial land available for human beings, and two-thirds of the global population, in more than 90 countries, reside in the topics. Most tropical countries are developing countries with abundant resources but poor economies, and face food shortages and serious nutrition problems. Therefore, the improvement of crop yield and promotion of biofortification in the field are important challenges for the future. 
However, the progress of research on the biology of tropical plants lags far behind that of main food crops, such as rice, maize and soybean. Multiple scientific issues are not well understood, such as extraordinary biomass accumulation associated with $\mathrm{C} 3-\mathrm{C} 4$ photosynthesis, the efficient biosynthesis and transport of carbohydrates in tropical climates, adaptation to extreme drought during the dry season, and adaption to barren soil and diverse biotic stresses in humid and high-temperature environments.

\section{Cassava as a tropical model plant}

Cassava (Manihot esculenta Crantz), a perennial species that originated from the Americas, is widely grown in tropical and sub-tropical Africa, Asia, and Latin America between latitudes $30^{\circ} \mathrm{N}$ and $30^{\circ} \mathrm{S}$. This species is not only the sixth most important staple food crop supplying food for more than 700 million people, but also a potential resource of animal feed, biofuel and biomaterials in the future. Cassava is known as the king of starchy plants due to its exceptionally high starch yield. The fresh storage root yield is as high as $75-90 \mathrm{t} \cdot \mathrm{ha}^{-1}$, which is equal to 22.5 $27 \mathrm{t} \cdot \mathrm{ha}^{-1}$ starch under favorable field conditions. Cassava's ability to produce in marginal environments where other food crops would fail makes it the ideal food security crop against famine in sub-Saharan Africa and Asia. Cassava is economically important due to its particular biological features. In terms of botany, physiology and genome characteristics, cassava should be an important biological model for tropical plants.

\subsection{Botanical features}

(1) The life cycle of cassava is generally $8-10$ months from planting to harvest, when storage root and seed harvest is completed. This cycle is much shorter than that of most other tropical plant species, especially the woody plants in tropical rainforests. (2) In plant structure, cassava plant size is moderate at $1-3 \mathrm{~m}$, with a long distance from the leaf source to the storage root sink. Photosynthates are transported through the long stem to the storage root, similar to woody rainforest species. (3) Flowering and sexual reproduction are simple for most lines of cultivated cassava. Cassava is a monoecious species producing both male and female flowers on the same plant, with indeterminate flowering. The fruit is a trilocular capsule, usually bearing 3 seeds. Artificial pollination and the acquisition of hybrid seeds are easy to achieve, which is a key trait of a tropical model plant. (4) Individual cassava plants can be propagated by stem cuttings for easy rooting and plantlet regeneration. This asexual propagation can maintain the heterosis and genotypes of seedlings, further enabling the generation of experimental populations for the discovery of genes and haplotypes with important traits for breeding [5].

\subsection{Genetics and systematics}

Cassava has a diploid genome $(2 n=36)$ of size $760 \mathrm{Mb}$ and is placed in the Manihot genus of the family Euphorbiaceae; a large family of flowering plants with 300 genera and approximately 7500 species. Most members of the Euphorbiaceae are herbs, but some, especially in the tropics, are shrubs or trees. This family occurs mainly in the tropics, with the majority of the species in the Indo-Malayan region, followed by tropical America and tropical Africa. A number of plants in this family are of considerable economic importance. Prominent plants include cassava (Manihot esculenta), Para rubber tree (Hevea brasiliensis), castor oil plant (Ricinus communis), and the Barbados nut (Jatropha curcas). Many of the plants in this region are grown as ornamental plants, such as poinsettia (Euphorbia pulcherrima). Manihot is a genus of approximately 98 species, including cassava, and originated in the tropical lowlands along the southern rim of the Amazon basin, the border of the tropical rainforest and the savanna, where sunlight, heat and rainfall are plentiful, and intervals of drought are common [6-8]. It is thought that domestication of cassava occurred between 12000 and 7000 years ago based on DNA sequence analysis of a single locus [6] and archeological and fossil records $[9,10]$. This domestication resulted in modern cassava cultivars with extraordinary characteristics, including a high biomass accumulation, high starch yield in nearoptimum environments and tolerance to drought and barren soil. There are approximately 13000 accessions of cassava germplasm in the Centro International de Agriculture Tropical (CIAT), Empresa Brasileira de Pesquisa Agropecuária and International Institute of Tropical Agriculture collections, enabling the discovery of a diversity of genes that are important for agriculture.

\subsection{Photosynthesis and physiological advantages}

Under optimal environmental conditions, cassava compares favorably in the production of energy with most other major staple food crops due to its high yield potential. Recent research at CIAT in Colombia has demonstrated the ability of cassava to assimilate carbon at very high rates under high levels of humidity, temperature and solar radiation, which correlates with the productivity across all environments whether dry or humid. When grown on very poor soils under prolonged drought for more than 6 months, the crop reduces both its leaf canopy and transpiration water loss, but its attached leaves remains photosynthetically active, albeit at greatly reduced rates. Both the total biomass and storage dry root yield correlate significantly with the mean seasonal upper canopy leaf photosynthetic rate, and these features are generally due to non-stomatal (biochemical and anatomical) factors $[11,12]$. 


\section{Cassava as a model for C3-C4 photosynthesis and starch accumulation}

Originally, cassava was believed to undergo C3-C4 photosynthesis because of several characteristics: the net photosynthetic rate is high, reaching 40 and $50 \mu \mathrm{mol} \cdot \mathrm{m}^{-2} \cdot \mathrm{s}^{-1} \mathrm{CO}_{2}$ under favorable field conditions with high solar radiation $\left(>1800 \mu \mathrm{mol} \cdot \mathrm{m}^{-2} \cdot \mathrm{s}^{-1}\right)$ and with an optimum leaf temperature around 30 to $35^{\circ} \mathrm{C}$ $[11,13,14]$. The activity of the $\mathrm{C} 4$ photosynthetic enzyme, phosphoenolpyruvate carboxylase (PEPC) is high, at 15\% to over $25 \%$ compared to that of the typical $\mathrm{C} 4$ species sorghum and maize. Cassava lacks the leaf Kranz anatomy characteristics of typical $\mathrm{C} 4$ species but it is different from typical C3 species [11,14-17]. The water-use efficiency is much greater than typical $\mathrm{C} 3$ species, such as sorghum, but the dry matter economic yield produced per unit water transpired mostly exceeds that of grain sorghum. Interestingly, these characteristics are not found in 20 wild species of cassava, including the ancestral subspecies, $M$. esculenta ssp. flabellifolia [18].

According to the comparative genome sequencing and annotation of the cultivars, inbred S3 generation of AM560 and non-inbred KU50, and the wild ancestor W14 [19,20], most of the genes in the photosynthesis and starch biosynthesis pathways have been restrictively selected during domestication and evolution. Selection pressure $(\mathrm{Ka} / \mathrm{Ks})$ analysis revealed that 1133 genes can be ascribed to the GO functional categories: (1) 'developmental process', 'metabolic process' and 'biological regulation', which are involved in the regulation of cell size, cellular metabolism, immunity and transcription, (2) 'response to stimulus', which includes abiotic stresses (such as light, temperature, water and oxygen), biotic stresses, (such as viral, bacterial and fungal infections) and responses to hormones (such as abscisic acid, ethylene, jasmonic acid and brassinosteroids). Comparative transcriptomic analysis further revealed that the cultivars show a particular transcript enrichment in genes that are involved in 'photosynthesis' and in shaping the photosynthetic organelles in leaves, and the genes that are included in the categories 'cell part', (especially the subcategories of 'cytoplast' and 'plasmid organelle') and 'response to stimulus' (particularly abscisic acid, oxidative stress and temperature) are only enriched in the storage roots of cultivars. A considerable number of genes that are involved in photosynthesis and the Calvin cycle in leaves and sucrose transport and starch synthesis in storage roots were preferentially expressed in the two cultivars compared to the wild ancestor W14. This result is consistent with the higher vigor and yield potential that are exhibited by KU50 and Arg7 relative to W14. There has also been an increase in copy numbers of some key genes related to photosynthesis and starch metabolism. Finally, a model of carbon flux divergence and starch efficient accumulation has been produced in cassava [20].

There is gap between the gene model at the genomic level and long-term genetic improvement for any crop [21]. However, the rapidly development of high-throughput and low-cost genomic sequencing technologies have helped to close this gap. Currently, in addition to the three former traditional genetic maps [22-24], a high density genetic map with more than 10000 SNP markers in 18 linkage groups (equal to the number of chromosomes) has been constructed in cassava based on the GBS (genotyping by sequencing) re-sequencing of 100 accessions (http:// www.cassavabase.org). Meanwhile, relying on a simplified resequencing technology known as amplified fragment SNP mining, a GWAS (genome-wide association study) for another 1000 diverse lines that are involved in the breeding system of South America, Africa and Asia, was carrying out and funded by the National Scientific Foundation of China-Concil Group of International Agriculture joint program, which will permit the fine mapping of the main traits of interest, which is essential for molecular design breeding. Importantly, this technological platform can also be used for other tropical crops.

\section{Cassava as a model for the efficient utilization of water and mineral nutrients}

Cassava has a remarkable tolerance to drought and barren soil underlying its efficient utilization of water, nitrogen, phosphate, potassium and other mineral nutrition [25]. This species is always cultivated in areas that are considered marginal for other crops, and it requires minimal inputs to gain a satisfactory yield, making cassava an important crop for drought-prone areas of tropical and sub-tropical Africa, Asia and Latin America.

When water is available, cassava maintains a high stomatal conductance with a high internal $\mathrm{CO}_{2}$ concentration, but when water becomes limiting, the stomata are closed in response to even small decreases in the soil water potential [25-28]. The cassava plant is also capable of partially retaining its photosynthetic capacity under prolonged water shortage. In addition, the leaf area growth decreases in response to water stress and is rapidly reversed following release from stress [29]. This drought tolerance mechanism leads to the high water-use efficiency of cassava. Although the cassava fine root system is sparse compared to that of other crops, it can penetrate more than $2 \mathrm{~m}$ into the soil, thereby, if available enabling the crop to exploit deep water. Large amounts of roots rapidly accumulate coincident with the slowdown of leaf expansion growth and transpiration, and the high abscisic acid (ABA) content is almost completely reversed to control levels after a short re-watering. A substantial proportion of the variation and subtle regulation of the ABA concentration can be precisely controlled by the genetics of cassava. 
Above all, the ability to regulate numerous plant processes to rapidly respond to unfavorable weather is key to the success of cassava [30]. The absorption, transport and utilization of macronutrients, nitrogen, phosphate and potassium have been well described for many plants $[31,32]$, but this information has been rarely reported for cassava. Comparative genome and transcriptome analysis has led to the annotation of the transporter gene families with a large proportion of the members for nitrate, phosphate salts and $\mathrm{K}^{+}$channel identified [20]. It will be useful to mine these genetic resources by elucidating the relationship with the related signaling pathways. Under drought stress, potassium salts were the major contributors to osmotic adjustment (OA), consistent with the increased ABA content in both mature and expanding leaves, accounting for approximately $60 \%$ of the osmotic potential [33].

A large amount of comparative transcriptome data has revealed that $\mathrm{ABA}$ and ethylene biosynthesis and their signaling pathways were significantly upregulated in response to water stress, during which drought-tolerant cultivars have more postive response than intolerant cultivars. Further KEGG annotation found that highly expressed genes that are involved in these responses are mainly upstream regulators, including important transcription factors and receptor proteins, such as b-ZIP, ARF, NAC transcription factor, RD26 in the ABA-dependent drought stress signaling pathway, and a homolog of a drought-inducible galactinol synthase [20,34]. Based on the successful embryo regeneration and transgenic system in cassava $[35,36]$, the functions of several key genes have been validated [37-39].

\section{Cassava as a model for adaptation to biotic stresses}

Diseases and pests are the most serious problems for cassava in South America and Africa, generally causing an annual yield loss of 30\%-60\% [40]. Cassava brown streak disease (CBSD) and cassava mosaic disease (CMD) are currently two major viral diseases that severely reduce cassava production in large areas of Sub-Saharan Africa. Natural resistance has so far only been reported for CMD. These two viruses both originated from East Africa at around the end of the Nineteenth Century, rather than from the center of origin of cassava in South America [41]. CBSD is caused by two distinct virus species, cassava brown streak virus (CBSV) and cassava brown streak Uganda virus (CBSUV). Both species belong to the genus Ipomovirus, family Potyviridae [42], and are transmitted by the whiteflies (Bemisia tabaci) [43]. CBSD rots the storage roots, reducing both the quality and quantity of the tubers that are available for consumption. Virus genome sequencing has revealed the evolution and diversity of
CBSV and CMV [42], and the transcriptional response of virus-infected cassava could elucidate resistance genes that are involved in hormone signaling pathways and production of secondary metabolites [43]. Transgenic technology was successfully used to control CBSD and CMD, however, this technology is not ready for field utilization. The transgenic lines showed a significant suppression of the disease in both of CBSD and CMD using a small interfering RNA strategy. An innovative combination of natural and engineered virus resistance will be particularly important for reducing the increasing impact of cassava viral diseases in Africa $[44,45]$. Cassava frog skin disease (CFSD), which affects the cassava storage roots, is also a serious disease in Latin America and Africa [46]. CFSD was first reported in Colombia in 1971, severely affecting roots in constriction zones and preventing the storage root from accumulating starch [47]. Presently, little information on this disease has been reported. Using inter-organismal genetics, the origin and evolution of these relatively new viruses could be evaluated by a comparison of the pathogen recognition of the host cultivars with the virusfree ecotypes from Africa and America. Cassava bacterial blight (CBB) caused by Xanthomonas axonopodis pv. manihotis (Xam) is widespread in all of the places where cassava is grown, including China [48]. CBB causes the symptoms of angular leaf spots, yellow stem exudates, stem lesions, blight, and dieback [49]. Few cultivars are resistant to Xam, and its spread and damage caused are mainly affected by humidity. Recently, one Xam strain was sequenced; ten clusters of pathogenicity factors, conserved within the genus, Xanthomonas and 126 genes that are potentially unique to Xam were found. This information will provide a basis for greater understanding of CBB [50].

Post-harvest physiological deterioration (PPD) uniquely takes place in the storage roots of cassava and is a major constraint to the cassava industry [51]. PPD is triggered within $24 \mathrm{~h}$ of harvest and rapidly renders the roots unpalatable. Post-harvest deterioration essentially involves oxidative and redox modulation [52]. A microarray predicted that the upregulated and PPD-specific expressed genes are involved in cellular processes, including reactive oxygen species turnover, cell wall repair, programmed cell death, ion, water or metabolite transport, signal transduction or perception and the activation of protein synthesis [53]. Large-scale proteomic analyses indicated a key function for ascorbate/glutathione cycles, highlighting glutathione peroxidase as a candidate for reducing PPD. Transgenic cassava overexpressing a cytosolic glutathione peroxidase in storage roots showed delayed PPD and reduced lipid peroxidation, as well as decreased $\mathrm{H}_{2} \mathrm{O}_{2}$ accumulation [54]. Overexpressing $\mathrm{Cu}$-superoxide dismutase (SOD), Zn-SOD and acyl-CoA oxidase in cassava roots also could delay PPD 7-21 days of under greenhouse and field trial conditions $[55,56]$. However, the details of the metabolic processes responsible for PPD in cassava are still not clear. 


\section{Present challenges and ongoing work}

Being the world's fourth-largest source of calories, cassava has the potential to become a more productive and more nutritious cropand this could be especially important in the tropics, alleviating malnutrition in much of the developing world. For practical purposes, several urgent constraints for field production and processing should be resolved: breeding cultivars with high yield and stable root storage as featured by the ideal plant type (Fig. 1), the efficient use of water and mineral nutrition, and field resistance to diseases and pests. Also, starch quality, dependent on the ratio of amylose and amylopectin, the fortification of vitamins, protein and mineral elements and the minimizing of cyanide content in the stored root are important factors for this food crop. However, how to breed these ideal cassava varieties? In theory and technological perspective, the present knowledge indicates that most of the genes in principal metabolism are subtly different in structure among cultivars and species even with significantly different phenotypes. The real challenge is to understand how the cassava plant senses and responds to environment signals (such as high temperature and light, and humidity in the air and soil), and to gain insights into regulatory networks by comparing them in diverse genotypes. Diverse wild Manihot spp. could be donors of special genes key to the improvement of cultivars that have been selected in past decades [57]. Using the genome sequences of the wild ancestor W14, the cultivar KU50 and the database (http://www.cassava-genome.cn), a roadmap for systematic biological research on cassava is provided (Fig. 2). By comparing W14 and KU50 (with domesticated genotypes) under controlled conditions, all of the major signals in response to environmental factors and network crosstalk information could be elucidated. A hybrid population between W14 and KU50 with more than 300 individuals is crucial for the discovery of the upstream gene switches and the fine mapping of all breeding traits. In particular, we should centralize the ABA signal pathway and transporters involved in potassium salts, nitrates and phosphates, which would enable us to identify the unique gene sources in cassava.In fact, some of improved varieties have been produced recently in cassava, including types with waxy starch, tolerance to PPD, resistance to CMD and CBSD, high protein content and minimal cyanide in storage roots by combining conventional breeding to biotechnology [58].

As a model for tropical biology, cassava has already acquired funding by the National Basic Research Program of China (2010CB126601) and the China Cassava Research System (CARS-12). Internationally, cassava has been sustainably funded by the Gates and Rockefeller Foundations, including through programs such as Biocassava Plus. Most of the collaborators in the cassava project are committed to changing the world and believe this is possible [59]. Indeed, cassava provides some special genetic resources that are key to high biomass accumulation, efficient use of water and mineral nutrition, fortification of human nutrients in storage roots and diverse resistance to diseases and pests in tropics and subtropics.

\section{Ecotype}

Height: $180-220 \mathrm{~cm}$

Plant shape: upper branching

Leaf angle: erect 45-60 degree

Leaf retention: 100 days

Stem diameter: $2.5-3.5 \mathrm{~cm}$

Harvest index: more than 0.60

Storage root number: $9-13$

Fresh root yield: $6^{-9} \mathrm{~kg}$ per plant
Adaptability

Height water-use efficiency

High N-P-K efficiency

CMD, CBSD and FSD free

Resistant to CBB

Tolerant to PPD

Starch quality specialized processing industry

Rish in vitamins and proteins for food

Life cycle: $8-10$ months

Fig. 1 An ideal plant type of a cassava cultivar with a high yield potential 


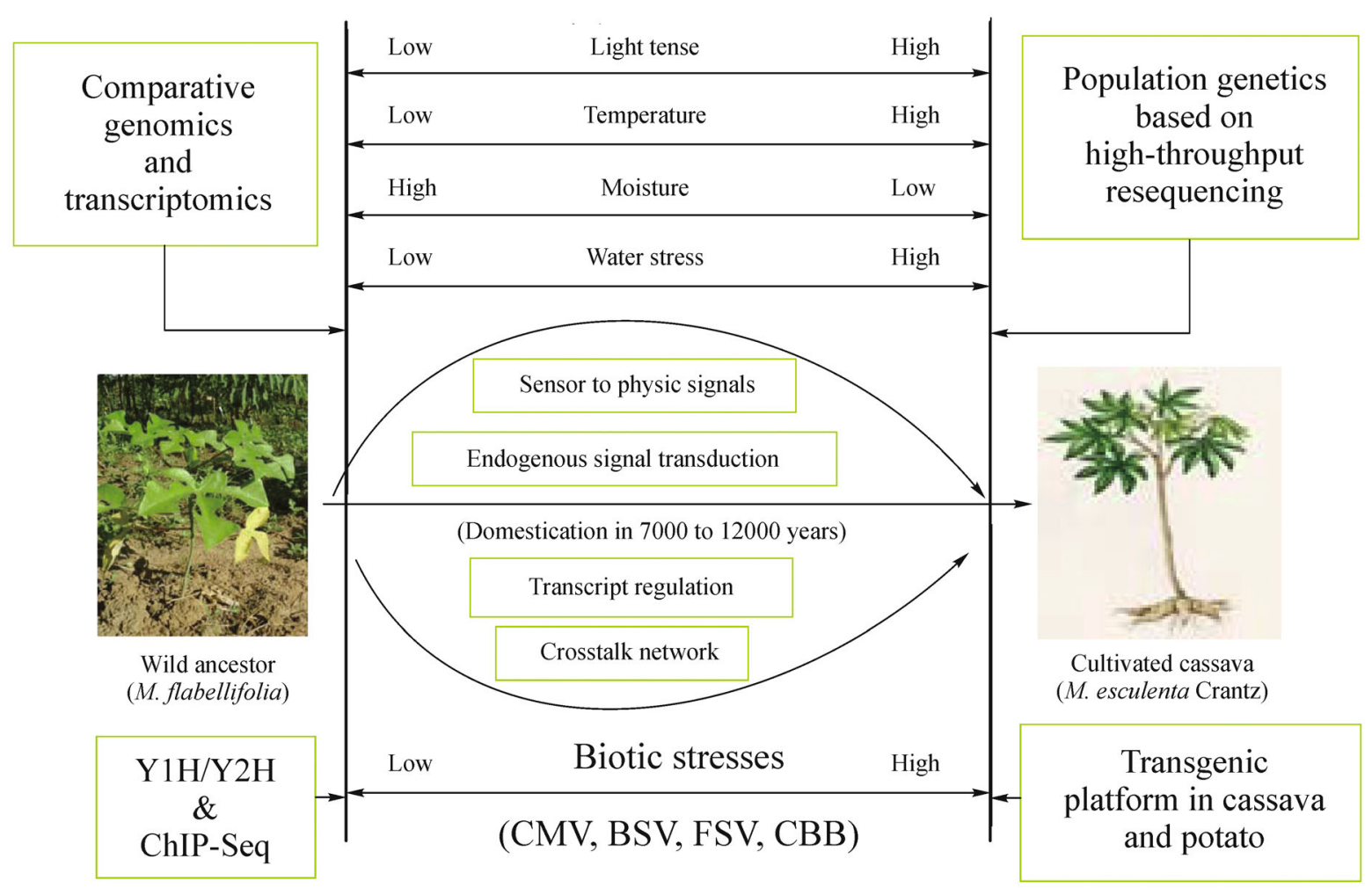

Fig. 2 Roadmap of the systemic genes and signal transduction network in cassava

Importantly, the enhancement of these genes is also valuable for the genetic improvement of other important tropical and non-tropical crops.

Acknowledgements This work was funded by the National Basic Research Program of China (2010CB126601), the National Natural Science Foundation of China (31261140363 and 31171230), the China Agriculture Research System (CARS-12), the National International Science and Technology Cooperation Plan (2011DFB31690), and the National High Technology Research and Development Program of China (2012AA101204-2).

Compliance with ethics guidelines Shengkui Zhang, Ping'an Ma, Haiyan Wang, Cheng Lu, Xin Chen, Zhiqiang Xia, Meiling Zou, Xinchen Zhou and Wenquan Wang declare that they have no conflict of interest or financial conflicts to disclose.

This article is a review and does not contain any studies with human or animal subjects performed by any of the authors.

\section{References}

1. Li P, Brutnell T P. Setaria viridis and Setaria italica, model genetic systems for the Panicoid grasses. Journal of Experimental Botany, 2011, 62(9): 3031-3037

2. Doust A N, Kellogg E A, Devos K M, Bennetzen J L. Foxtail millet: a sequence- driven grass model system. Plant Physiology, 2009, 149 (1): 137-141

3. Brutnell T P, Wang L, Swartwood K, Goldschmidt A, Jackson D, Zhu X G, Kellogg E, Van Eck J. Setaria viridis: a model for C4 photosynthesis. Plant Cell, 2010, 22(8): 2537-2544

4. Diao X, Schnable J, Bennetzen J L, Li J. Initiation of Setaria as a model plant. Frontiers of Agricultural Science and Engineering, 2014, 1(1): 16-20

5. Fregene M. Cassava biotechnology. In: Hillocks R J. Cassava: biology, production and utilization. CAB International, 2002: 179207

6. Allem A C. The origin of Manihot esculenta Crantz (Euphorbiaceae). Genetic Resources and Crop Evolution, 1994, 41(3): 133-150

7. Allem A C. The closest wild relatives of cassava (Manihot esculenta Crantz). Euphytica, 1999, 107(1): 123-133

8. Olsen K M, Schaal B A. Evidence on the origin of cassava: phylogeography of Manihot esculenta. Proceedings of the National Academy of Sciences of the United States of America, 1999, 96(10): 5586-5591

9. Bartlett A S, Barghoorn E S, Berger R. Fossil maize from Panama. Science, 1969, 165(3891): 389-390

10. Gibbons A. New view of early Amazonia: recent findings suggest complex culture was indigenous to the Amazon Basin-upsetting some received opinions about environment and culture. Science, 1990, 248(4962): 1488-1490

11. El-Sharkawy M A, Cock J H. Photosynthesis of cassava (Manihot esculenta). Experimental Agriculture, 1990, 26(03): 325-340

12. El-Sharkawy M A, Cock J H, Lynam J K, del Pilar Hernàndez A, Cadavid L F L. Relationships between biomass, root-yield and single-leaf photosynthesis in field-grown cassava. Field Crops Research, 1990, 25(3-4): 183-201

13. El-Sharkawy M A, Cock J H, Held A A. Photosynthetic responses 
of cassava cultivars (Manihot esculenta Crantz) from different habitats to temperature. Photosynthesis Research, 1984, 5(3): 243250

14. El-Sharkawy M A, De Tafur S M, Cadavid L F. Potential photosynthesis of cassava as affected by growth conditions. Crop Science, 1992, 32(6): 1336-1342

15. El-Sharkawy M A, Cock J H, De Cadena G. Influence of differences in leaf anatomy on net photosynthetic rates of some cultivars of cassava. Photosynthesis Research, 1984, 5(3): 235-242

16. Cock J H, Riaño N M, El-Sharkawy M A, Lopez Y, Bastidas G. C3$\mathrm{C} 4$ intermediate photosynthetic characteristics of cassava (Manihot esculenta Crantz). II. Initial products of ${ }^{14} \mathrm{CO}_{2}$ fixation. Photosynthesis Research, 1987, 12(3): 237-241

17. El-Sharkawy M A, Cock J H. C3-C4 intermediate photosynthetic characteristics of cassava (Manihot esculenta Crantz). I. Gas exchange. Photosynthesis Research, 1987, 12(3): 219-235

18. Calatayud P A, Barón C H, Velásquez H, Arroyave J A, Lamaze T. Wild manihot species do not possess $\mathrm{C} 4$ photosynthesis. Annals of Botany, 2002, 89(1): 125-127

19. Prochnik S, Marri P R, Desany B, Rabinowicz P D, Kodira C, Mohiuddin M, Rodriguez F, Fauquet C, Tohme J, Harkins T, Rokhsar D S, Rounsley S. The cassava genome: current progress, future directions. Tropical Plant Biology, 2012, 5(1): 88-94

20. Wang W, Feng B, Xiao J, Xia Z, Zhou X, Li P, Zhang W, Wang Y, Møller B L, Zhang P, Luo M C, Xiao G, Liu J, Yang J, Chen S, Rabinowicz P D, Chen X, Zhang H B, Ceballos H, Lou Q, Zou M, Carvalho L J, Zeng C, Xia J, Sun S, Fu Y, Wang H, Lu C, Ruan M, Zhou S, Wu Z, Liu H, Kannangara R M, Jørgensen K, Neale R L, Bonde M, Heinz N, Zhu W, Wang S, Zhang Y, Pan K, Wen M, Ma P A, Li Z, Hu M, Liao W, Hu W, Zhang S, Pei J, Guo A, Guo J, Zhang J, Zhang Z, Ye J, Ou W, Ma Y, Liu X, Tallon L J, Galens K, Ott S, Huang J, Xue J, An F, Yao Q, Lu X, Fregene M, López-Lavalle L A B, Wu J, You F M, Chen M, Hu S, Wu G, Zhong S, Ling P, Chen Y, Wang Q, Liu G, Liu B, Li K, Peng M. Cassava genome from a wild ancestor to cultivated varieties. Nature Communications, 2014, 5: 5110

21. Morris G P, Ramu P, Deshpande S P, Hash C T, Shah T, Upadhyaya H D, Riera-Lizarazu O, Brown P J, Acharya C B, Mitchell S E, Harriman J, Glaubitz J C, Buckler E S, Kresovich S. Population genomic and genome-wide association studies of agroclimatic traits in sorghum. Proceedings of the National Academy of Sciences of the United States of America, 2013, 110(2): 453-458

22. Rabbi I Y, Kulembeka H P, Masumba E, Marri P R, Ferguson M. An EST-derived SNP and SSR genetic linkage map of cassava (Manihot esculenta Crantz). Theoretical and Applied Genetics, 2012, 125(2): 329-342

23. Chen X, Xia Z, Fu Y, Lu C, Wang W. Constructing a genetic linkage map using an F1 population of non-inbred parents in cassava (Manihot esculenta Crantz). Plant Molecular Biology Reporter, 2010, 28(4): 676-683

24. Kunkeaw S, Yoocha T, Sraphet S, Boonchanawiwat A, Boonseng O, Lightfoot D A, Triwitayakorn K, Tangphatsornruang S. Construction of a genetic linkage map using simple sequence repeat markers from expressed sequence tags for cassava (Manihot esculenta Crantz). Molecular Breeding, 2011, 27(1): 67-75

25. El-Sharkawy M A, De Tafur S M, Cadavid L F. Photosynthesis of cassava and its relation to crop productivity. Photosynthetica, 1993, 28: 431-438

26. El-Sharkawy M A, Cock J H. The humidity factor in stomatal control and its effects on crop productivity. In: R. Marcelle R, Clijsters H, van Poucke M, eds. Biological Control of Photosynthesis. Dordrecht: Martinus Nijhoff Publishers, 1986, 187-198

27. El-Sharkawy M A, Cock J H, Held K A A. Water use efficiency of cassava. II. Differing sensitivity of stomata to air humidity in cassava and other warm-climate species. Crop Science, 1984, 24(3): 503-507

28. El-Sharkawy M A, Cock J H, Del Pilar Hernandez A. Stomatal response to air humidity and its relation to stomatal density in a wide range of warm climate species. Photosynthesis Research, 1985, 7 (2): 137-149

29. Alves A A, Setter T L. Response of cassava leaf area expansion to water deficit: cell proliferation, cell expansion and delayed development. Annals of Botany, 2004, 94(4): 605-613

30. Okogbenin E, Setter T L, Ferguson M, Mutegi R, Ceballos H, Olasanmi B, Fregene M. Phenotypic approaches to drought in cassava: review. Frontiers in Physiology, 2013, 4: 1-15

31. Hubbard K E, Nishimura N, Hitomi K, Getzoff E D, Schroeder J I. Early abscisic acid signal transduction mechanisms: newly discovered components and newly emerging questions. Genes \& Development, 2010, 24(16): 1695-1708

32. Zelazny E, Vert G. Plant nutrition: root transporters on the move. Plant Physiology, 2014, 166(2): 500-508

33. Alves A A C, Setter T L. Abscisic acid accumulation and osmotic adjustment in cassava under water deficit. Environmental and Experimental Botany, 2004, 51(3): 259-271

34. Utsumi Y, Tanaka M, Morosawa T, Kurotani A, Yoshida T, Mochida K, Matsui A, Umemura Y, Ishitani M, Shinozaki K, Sakurai T, Seki M. Transcriptome analysis using a high-density Oligomicroarray under drought stress in various genotypes of cassava: an important tropical Crop. DNA Research, 2012, 19(4): 335-345

35. Li H Q, Sautter C, Potrykus I, Puonti-Kaerlas J. Genetic transformation of cassava (Manihot esculenta Crantz). Nature Biotechnology, 1996, 14(6): 736-740

36. Schöpke C, Taylor N, Cárcamo R, Konan N K, Marmey P, Henshaw G G, Beachy R N, Fauquet C. Regeneration of transgenic cassava plants (Manihot esculenta Crantz) from microbombarded embryogenic suspension cultures. Nature Biotechnology, 1996, 14(6): 731735

37. Zhang P, Jaynes J M, Potrykus I, Gruissem W, Puonti-Kaerlas J. Transfer and expression of an artificial storage protein (ASPl) gene in cassava (Manihot esculenta Crantz). Transgenic Research, 2003, 12(2): 243-250

38. Zhang P, Bohl-Zenger S, Puonti-Kaerlas J, Potrykus I, Gruissem W. Two cassava promoters related to vascular expression and storage root formation. Planta, 2003, 218(2): 192-203

39. Welsch R, Arango J, Bär C, Salazar B, Al-Babili S, Beltrán J, Chavarriaga $\mathrm{P}$, Ceballos $\mathrm{H}$, Tohme J, Beyer P. Provitamin A accumulation in cassava (Manihot esculenta) roots driven by a single nucleotide polymorphism in a phytoene synthase gene. Plant Cell, 2010, 22(10): 3348-3356

40. Legg J P, Thresh J M. Cassava virus diseases in Africa. In: Hughes J 
d'A, Odu B O, eds. Plant Virology in Sub-Saharan Africa, Ibadan, Nigeria. International Institute of Tropical Agriculture, 2004, 517552

41. Legg J P, Thresh J M. Cassava mosaic virus disease in East Africa: a dynamic disease in a changing environment. Virus Research, 2000, 71(1-2): 135-149

42. Monger W A, Seal S, Isaac A M, Foster G D. Molecular characterization of the cassava brownstreak virus coat protein. Plant Pathology, 2001, 50(4): 527-534

43. Maruthi M N, Hillocks R J, Mtunda K, Raya M D, Muhanna M, Kiozia H, Rekha A R, Colvin J, Thresh J M. Transmission of Cassava brown streak virus by Bemisia tabaci (Gennadius). Journal of Phytopathology, 2005, 153(5): 307-312

44. Ogwok E, Odipio J, Halsey M, Gaitán-Solís E, Bua A, Taylor N J, Fauquet C M, Alicai T. Transgenic RNA interference (RNAi)derived field resistance to cassava brown streak disease. Molecular Plant Pathology, 2012, 13(9): 1019-1031

45. Vanderschuren H, Moreno I, Anjanappa R B, Zainuddin I M, Gruissem W. Exploiting the combination of natural and genetically engineered resistance to cassava mosaic and cassava Brown streak viruses impacting cassava production in Africa. PLoS ONE, 2012, 7 (9): e45277

46. Pineda B, Jayasinghe U, Lozano J C. La enfermedad "cuero de sapo" en yuca (Manihot esculenta Crantz). Asiava, 1983, 4: 10-12

47. Carvajal-Yepes M, Olaya C, Lozano I, Cuervo M, Castaño M, Cuellar W J. Unraveling complex viral infections in cassava (Manihot esculenta Crantz) from Colombia. Virus Research, 2014, 186: $76-86$

48. Lozano J C. Cassava bacterial blight: a manageable disease. Plant Disease, 1986, 70(12): 1089-1093

49. Maraite H. Xanthomonas campestris pathovars on cassava: cause of bacterial blight and bacterial necrosis. In: Swings J G, Civerolo E L, eds. Xanthomonas. Chapman and Hall, 1993, 18-24

50. Arrieta-Ortiz M L, Rodríguez-R L M, Pérez-Quintero Á, Poulin L, Díaz A C, Arias Rojas N, Trujillo C, Restrepo Benavides M, Bart R, Boch J, Boureau T, Darrasse A, David P, Dugé de Bernonville T, Fontanilla P, Gagnevin L, Guérin F, Jacques M A, Lauber E, Lefeuvre P, Medina C, Medina E, Montenegro N, Muñoz Bodnar A, Noël L D, Ortiz Quiñones J F, Osorio D, Pardo C, Patil P B, Poussier
S, Pruvost O, Robène-Soustrade I, Ryan R P, Tabima J, Urrego Morales O G, Vernière C, Carrere S, Verdier V, Szurek B, Restrepo S, López C, Koebnik R, Bernal A. Genomic survey of pathogenicity determinants and VNTR markers in the cassava bacterial pathogen Xanthomonas axonopodis pv. Manihotis strain CIO151. PLoS ONE, 2013, 8(11): e79704

51. Reilly K, Gómez-Vásquez R, Buschmann H, Tohme J, Beeching J R. Oxidative stress responses during cassava post-harvest physiological deterioration. Plant Molecular Biology, 2004, 56(4): 625641

52. Owiti J, Grossmann J, Gehrig P, Dessimoz C, Laloi C, Hansen M B, Gruissem W, Vanderschuren H. iTRAQ-based analysis of changes in the cassava root proteome reveals pathways associated with postharvest physiological deterioration. Plant Journal, 2011, 67(1): 145-156

53. Reilly K, Bernal D, Cortés D F, Gómez-Vásquez R, Tohme J, Beeching J R. Towards identifying the full set of genes expressed during cassava post-harvest physiological deterioration. Plant Molecular Biology, 2007, 64(1-2): 187-203

54. Vanderschuren H, Nyaboga E, Poon J S, Baerenfaller K, Grossmann J, Hirsch-Hoffmann M, Kirchgessner N, Nanni P, Gruissem W. Large-scale proteomics of the cassava storage root and identification of a target gene to reduce postharvest deterioration. Plant Cell, 2014, 26(5): 1913-1924

55. Zidenga T, Leyva-Guerrero E, Moon H, Siritunga D, Sayre R. Extending cassava root shelf life via reduction of reactive oxygen species production. Plant Physiology, 2012, 159(4): 1396-1407

56. Xu J, Duan X, Yang J, Beeching J R, Zhang P. Enhanced reactive oxygen species scavenging by overproduction of superoxide dismutase and catalase delays postharvest physiological deterioration of cassava storage roots. Plant Physiology, 2013, 161(3): 15171528

57. Nassar N, Ortiz R. Breeding cassava to feed the poor. Scientific American, 2010, 302(5): 78-84

58. Gbadegesin M, Olaiya C O, Beeching J R. African cassava: biotechnology and molecular breeding to the rescue. British Biotechnology Journal, 2013, 3(3): 305-317

59. Marris E. Agronomy: five crop researchers who could change the world. Nature, 2008, 456(7222): 563-568 